Wayne State University

DigitalCommons@WayneState

Geology Faculty Research Publications

Geology

$12-1-1991$

\title{
Environmental Radiocesium in Subarctic and Arctic Alaska Following Chernobyl
}

\author{
M. Baskaran \\ Texas A \& M University - Galveston, baskaran@wayne.edu \\ J.J. Kelley \\ University of Alaska Fairbanks, jjkelley@alaska.edu \\ A. S. Naidu \\ University of Alaska Fairbanks, sanaidu@alaska.edu \\ D. F. Holleman \\ University of Alaska Fairbanks
}

\section{Recommended Citation}

Environmental Radiocesium in Subarctic and Arctic Alaska Following Chernobyl

M. Baskaran, J. J. Kelley, A. S. Naidu and D. F. Holleman

Arctic, Vol. 44, No. 4 (Dec., 1991), pp. 346-350

Available at: http://digitalcommons.wayne.edu/geofrp/14

This Article is brought to you for free and open access by the Geology at DigitalCommons@WayneState. It has been accepted for inclusion in Geology Faculty Research Publications by an authorized administrator of DigitalCommons@WayneState. 


\title{
Environmental Radiocesium in Subarctic and Arctic Alaska Following Chernobyl
}

\author{
M. BASKARAN, ${ }^{1}$ J.J. KELLEY, ${ }^{2}$ A.S. NAIDU ${ }^{2}$ and D.F. HOLLEMAN ${ }^{3}$
}

(Received 31 May 1990; accepted in revised form 6 March 1991)

\begin{abstract}
Radiocesium $\left({ }^{134} \mathrm{Cs}\right.$ and ${ }^{137} \mathrm{Cs}$ ) concentrations were measured in soil, plant and wildlife samples from subarctic to arctic Alaska. Concentrations of ${ }^{137} \mathrm{Cs}$ ranged from below detectable or low levels in whale and fish samples to as high as $242 \mathrm{~Bq} / \mathrm{kg}$ in lichen. For all potential human food items, the radiocesium concentrations measured in this study were below accepted permissible levels for human consumption. Chernobyl-derived radiocesium concentrations ranged from below detectable or low levels in all arctic samples (soil, sediment, lichen, whale, fish and caribou) to $32 \mathrm{~Bq} / \mathrm{kg}$ in subarctic moss. Therefore the distribution and subsequent deposition of Chernobyl-derived radiocesium appears to be variable but decreasing significantly from the Subarctic (Fairbanks) to the Arctic. The present data support the suggestion that Chernobyl-derived debris arrived from western Canada into central Alaska and subsequently moved to the north (arctic) and to the west, decreasing in the quantity deposited as the debris transversed the state.
\end{abstract}

Key words: Chernobyl, radiocesium, lichen, mushroom, caribou, reindeer, soil, fallout, deposition

RÉSUMÉ. On a mesuré les concentrations de césium radioactif $\left({ }^{134} \mathrm{Cs}\right.$ et $\left.{ }^{137} \mathrm{Cs}\right)$ dans des échantillons de sol, de plantes et d'animaux, dans la région allant de l'Alaska subarctique à l'Alaska arctique. Les concentrations de ${ }^{137} \mathrm{Cs}$ allaient de niveaux peu élevés ou inférieurs au point de détection dans des échantillons de baleine et de poisson, à des niveaux qui atteignaient $242 \mathrm{~Bq} / \mathrm{kg}$ dans le lichen. Pour toutes les formes potentielles d'alimentation humaine, les concentrations de césium radioactif mesurées au cours de l'étude étaient inférieures au niveau reconnu acceptable pour la consommation humaine. Les concentrations de césium radioactif provenant de Chemobyl allaient de niveaux peu élevés ou inférieurs au point de détection dans tous les échantillons provenant de l'Arctique (sol, sédiments, lichen, baleine, poisson et caribou), à $32 \mathrm{~Bq} / \mathrm{kg}$ dans la mousse subarctique. La répartition et le dépôt subséquent du césium radioactif provenant de Chernobyl semblent donc varier, selon un mode nettement décroissant du Subarctique (Fairbanks) à l'Arctique. Les données actuelles viennent appuyer l'hypothèse que les débris provenant de Chernobyl sont arrivés de l'ouest du Canada dans le centre de l'Alaska et se sont ensuite déplacés vers le nord (Arctique) et vers l'ouest, se déposant en quantité décroissante au fur et à mesure qu'ils traversaient l'État.

Mots clés: Chernobyl, césium radioactif, lichen, champignon, caribou, renne, sol, retombées, dépôt

Traduit pour le journal par Nésida Loyer.

\section{INTRODUCTION}

It has been estimated that for all fallout radionuclides from atmospheric weapons testing, radiocesium alone (primarily ${ }^{137} \mathrm{Cs}$ ) contributes about $50 \%$ of the total radiation dose to humans in the Northern Hemisphere (Goldman, 1987). Recognizing the importance of radiocesium in radiation dosimetry, investigators have focused considerable attention on fallout radiocesium and its movement in the subarctic and arctic food chain, especially the fallout to lichen to caribou/reindeer to human/wolf food chain (Baarli et al., 1961; Palmer et al., 1963; Liden and Gustafson, 1967; Miettinen and Hasanen, 1967; Hanson, 1967, 1982; Holleman et al., 1971; Holleman and Stephenson, 1981; White et al., 1986; Skogland, 1987).

There has been a gradual decrease in bioavailable radiocesium since the cessation of atmospheric weapons testing; thus for Alaska, radiocesium concentrations in lichen, caribou and reindeer have decreased from peak concentrations of 1200 $1800 \mathrm{~Bq} / \mathrm{kg}$ in the mid-1960s to less than $300 \mathrm{~Bq} / \mathrm{kg}$ in January 1986 (White et al., 1986). The total amount of radiocesium discharged into the atmosphere following the Chernobyl accident on 26 April 1986 was at most 5-10\% of the total amount of radiocesium released from all atmospheric nuclear weapons tests (Goldman, 1987). However, the Chernobyl radiocesium radiation dose to humans in the Northern Hemisphere has been estimated to be about $60 \%$ of the total radiocesium radiation dose from the earlier atmospheric weapons tests (Goldman, 1987). This unusually high radiation dose from a significantly smaller quantity of atmospheric released radiocesium is primarily due to the relatively close proximity of large human populations near the
Chernobyl accident site, namely, in the central U.S.S.R. and eastern Europe.

Chernobyl-derived radiocesium can be identified by the presence of ${ }^{134} \mathrm{Cs}$ and provides a unique means to assess the pattern of environmental distribution, deposition and subsequent movement of fallout radionuclides from a single event occurring in the Northern Hemisphere. Knowledge of such patterns for atmospheric released radionuclides from the Chernobyl accident may be helpful in evaluating the potential effects of future accidents as well as in understanding the transport pathways and processes of radionuclides associated with such accidents in the atmospheric, terrestrial and aquatic reservoirs (Santschi et al., 1988). Highly variable regional deposition rates of Chernobyl-derived radionuclides have been reported from Scandinavia, Germany, the United Kingdom and the Mediterranean region, as suggested by the wide-ranging values, for example, from 40 to several thousand $\mathrm{Bq} / \mathrm{m}^{2}$ (Davidson et al., 1987; Santschi et al., 1988). In the western United States, the total deposition rate of ${ }^{134} \mathrm{Cs}$ was typically $37-74 \mathrm{~Bq} / \mathrm{m}^{2}$, while at several locations in the Midwest and on the east coast, the values ranged from 3.7 to $37 \mathrm{~Bq} / \mathrm{m}^{2}$ (Davidson et al., 1987). In Alaska, the radiocesium deposition rate was estimated at approximately $0.5 \mathrm{~Bq} / \mathrm{m}^{2}$ for the period April 1986 (pre-Chernobyl) to August 1986 (post-Chernobyl) for the Fairbanks area (White et al., 1986). There is some indirect evidence suggesting wide regional differences in the deposition rate of the Chernobyl-derived radionuclides in Alaska. For example, some airborne measurements show that the integrated radioiodine $\left({ }^{131} \mathrm{I}\right)$ concentrations are significantly different in Fairbanks and Barrow (unpubl. data, Kipphut, 1986), which could lead to differences in the deposition rates.

\footnotetext{
${ }^{1}$ Department of Marine Science, Texas A\&M University, Galveston, Texas 77553-1675, U.S.A.

${ }^{2}$ Institute of Marine Science, University of Alaska Fairbanks, Fairbanks, Alaska 99775-1080, U.S.A.

${ }^{3}$ Institute of Arctic Biology, University of Alaska Fairbanks, Fairbanks, Alaska 99775-0180, U.S.A.

(CThe Arctic Institute of North America
} 
The objective of the present investigation was to determine radiocesium concentrations in selected environmental samples in subarctic and arctic Alaska. In addition, ${ }^{134} \mathrm{Cs}$ was used to determine the variability and extent of Chernobyl-derived radiocesium in the environment.

\section{MATERIALS AND METHODS}

The locations and brief descriptions of the samples used in this study are given in Figure 1 and Table 1. Samples of soil, mixed lichens (primarily Cladonia spp.), mushrooms (mixed unidentified spp.), mosses (Sphagnum spp.), ledum (Ledum spp.), bowhead whale (Balaena mysticetus), two anadromous fishes (humpback white fish, Coregonus clupeaformus; arctic least cisco, Coregonus sardinella) and caribou (Rangifer tarandus) were obtained from arctic Alaska. Additional samples of lichens and mushrooms were collected from Ester Dome near Fairbanks. A single lichen sample was collected in extreme western Alaska near Nome. Samples of about 30-60 g of dried soil, $2-11 \mathrm{~g}$ of dried lichen/moss/ledum and $60 \mathrm{~g}$ of wet (frozen until ground) whale/fish/caribou muscle were ground using a blender. The ground samples were transferred into aluminum cans, capped and then analyzed using a Princeton Gamma (GeLi) detector coupled to a 4096 Channel Multichannel Analyzer (Canberra Industries, Inc.). The detector was shielded by approximately $10 \mathrm{~cm}$ of lead and there were no ${ }^{134} \mathrm{Cs}$ or ${ }^{137} \mathrm{Cs}$ peaks in the background spectrum.

TABLE 1. Collection site, date and description of samples

\begin{tabular}{|c|c|c|c|}
\hline $\begin{array}{l}\text { Sample } \\
\text { code }\end{array}$ & Material & $\begin{array}{c}\text { Collection } \\
\text { date }\end{array}$ & $\begin{array}{l}\text { Collection } \\
\text { site }\end{array}$ \\
\hline \multicolumn{4}{|c|}{ Arctic samples } \\
\hline A1 & soil, lichen & 1987 & Unknown site on arctic coast \\
\hline A2 & soil, lichen & 1987 & Atkasuk $\left(70.0^{\circ} \mathrm{N}, 156.3^{\circ} \mathrm{W}\right)$ \\
\hline A3 & lichen & 1987 & Unknown site on arctic coast \\
\hline A4 & soil, lichen & 1987 & $\begin{array}{l}\text { Anaktuvuk Pass } \\
\left(68.1^{\circ} \mathrm{N}, 151.7^{\circ} \mathrm{W}\right)\end{array}$ \\
\hline A5 & lichen & 1987 & Anaktuvuk Pass \\
\hline A6 & soil, lichen & 1987 & Unknown site on arctic coast \\
\hline A7 & soil, lichen & 1987 & $\begin{array}{l}\text { Research site } \\
\quad\left(68.5^{\circ} \mathrm{N}, 149.3^{\circ} \mathrm{W}\right)\end{array}$ \\
\hline A8 & lake sediment & 1987 & $\begin{array}{l}\text { Barrow Lake } \\
\left(71.2^{\circ} \mathrm{N}, 156.7^{\circ} \mathrm{W}\right)\end{array}$ \\
\hline A9 & white fish & 1987 & $\begin{array}{l}\text { Colville River } \\
\left(70.0^{\circ} \mathrm{N}, 151.0^{\circ} \mathrm{W}\right)\end{array}$ \\
\hline A 10 & least Cisco & 1987 & Colville River \\
\hline A 11 & bowhead whale & e 1987 & $\begin{array}{l}\text { Arctic Ocean } \\
\quad\left(71.0^{\circ} \mathrm{N}, 157.0^{\circ} \mathrm{W}\right)\end{array}$ \\
\hline A12 & bowhead whale & e 1987 & Arctic Ocean \\
\hline A13 & caribou & Oct. 1985 & Barrow $\left(71.2^{\circ} \mathrm{N}, 156.7^{\circ} \mathrm{W}\right)$ \\
\hline A14 & caribou & Nov. 1986 & Barrow \\
\hline A15 & caribou & Sept. 1987 & Colville River \\
\hline \multicolumn{4}{|c|}{ Subarctic samples } \\
\hline S1-S2 & lichen & July 1988 & $\begin{array}{l}\text { Fairbanks } \\
\qquad\left(64.8^{\circ} \mathrm{N}, 147.7^{\circ} \mathrm{W}\right)\end{array}$ \\
\hline S3 & moss & July 1988 & Fairbanks \\
\hline S4 & ledum & July 1988 & Fairbanks \\
\hline S5-S9 & mushrooms & Aug. 1988 & Fairbanks \\
\hline S10 & lichen & 1987 & $\begin{array}{l}\text { Nome } \\
\qquad\left(64.5^{\circ} \mathrm{N}, 165.2^{\circ} \mathrm{W}\right)\end{array}$ \\
\hline
\end{tabular}

Counting times ranged from 12 to $48 \mathrm{~h}$. The minimum detection limits were 0.21 and $0.28 \mathrm{~Bq} / \mathrm{kg}$ for ${ }^{134} \mathrm{Cs}$ and ${ }^{137} \mathrm{Cs}$ respectively, based on a $48 \mathrm{~h}$ count and the $95 \%$ confidence level. The details on the counting procedure and data analysis are given in Baskaran et al. (1988).

For those samples in which ${ }^{134} \mathrm{Cs}$ was detected, the quantity of ${ }^{137} \mathrm{Cs}$ that was derived from the Chernobyl accident was calculated. The procedure and its assumptions are as follows. Due to its relatively short physical half-life $(2.05 \mathrm{yr})$, all ${ }^{134} \mathrm{Cs}$ was assumed to be Chernobyl-derived. The ${ }^{137} \mathrm{Cs} /{ }^{134} \mathrm{Cs}$ ratio for Chernobyl released radiocesium at the time of the accident, 26 April 1986, was taken to be equal to 2.5 (Watson, 1986; Davidson et al., 1987). A decay corrected ratio was calculated by correcting for physical decay of both isotopes from the time of accident to the time of sample assay. The Chernobylderived ${ }^{137} \mathrm{Cs}$ concentration of the sample was calculated as the product of the measured ${ }^{134} \mathrm{Cs}$ concentration and the decay corrected ratio. All radiocesium concentrations are reported in $\mathrm{Bq} / \mathrm{kg}$ as of the time of counting, winter 1988.

\section{RESULTS AND DISCUSSION}

The total concentrations of ${ }^{134} \mathrm{Cs}$ and ${ }^{137} \mathrm{Cs}$ in the samples as well as the ${ }^{137} \mathrm{Cs}$ concentrations derived from the Chernobyl accident are given in Table 2 . The radiocesium concentrations are presented as radioactivity per unit dry-weight for the soil and plant samples and as radioactivity per unit wet-weight for the fish, whale and caribou samples. The errors in the activity are propagated 1 sigma error arising from counting statistics, background and efficiency of the detector.

\section{${ }^{137}$ Cs Concentration in Soils and Lichens}

${ }^{137} \mathrm{Cs}$ levels in the arctic soil samples analyzed are generally lower than in the arctic lichens and the ${ }^{134} \mathrm{Cs}$ levels are below detection limit in all the soil samples (Table 2). The ${ }^{137} \mathrm{Cs}$ concentrations ranged from 2.1 to $44.0 \mathrm{~Bq} / \mathrm{kg}$, with a geometric mean of $7.3 \mathrm{~Bq} / \mathrm{kg}$, in the soil samples and from 16.3 to $24.2 \mathrm{~Bq} / \mathrm{kg}$, with a geometric mean of $59.9 \mathrm{~Bq} / \mathrm{kg}$, in lichen samples. This range of ${ }^{137} \mathrm{Cs}$ concentration is comparable to the range of $59-181 \mathrm{~Bq} / \mathrm{kg}$ reported earlier for lichens in the study area just before the Chernobyl accident (Hanson, 1982; White et al., 1986). However, the mean concentration $(59.9 \mathrm{~Bq} / \mathrm{kg})$ of our arctic lichen samples is much lower than the values (approximately $600 \mathrm{~Bq} / \mathrm{kg}$ ) expected from the physical decay of ${ }^{137} \mathrm{Cs}$ for the values reported between 1962 and $1968(925-1100 \mathrm{~Bq} / \mathrm{kg})$. The ratio of ${ }^{137} \mathrm{Cs}$ concentration in lichens to soils varies from 0.51 to 28.2 (ratio of geometric mean $=59.9 / 7 \cdot 3=8 \cdot 2$ ). Earlier studies have shown that the ${ }^{137} \mathrm{Cs}$ concentrations in lichens were about five times those in soil (Hanson, 1982). The ratios of less than 1.0 could be due to new lichen growth that has been exposed to low levels of fallout ${ }^{137}$ Cs.

\section{${ }^{137} \mathrm{Cs}$ Concentrations in Fish and Whale Tissues}

Of the two fish analyzed, the freshwater species (humpback whitefish) had ${ }^{137} \mathrm{Cs}$ concentration below the detection limit, while that of the estuarine fish (least cisco whitefish) had a low concentration $(0.52+0.09 \mathrm{~Bq} / \mathrm{kg})$. The ${ }^{137} \mathrm{Cs}$ concentration was below the detection limit in bowhead whale blubber and liver, while the muscle sample had a low concentration of ${ }^{137} \mathrm{Cs}(0.57 \mathrm{~Bq} / \mathrm{kg})$. This may be expected since fallout radio- 


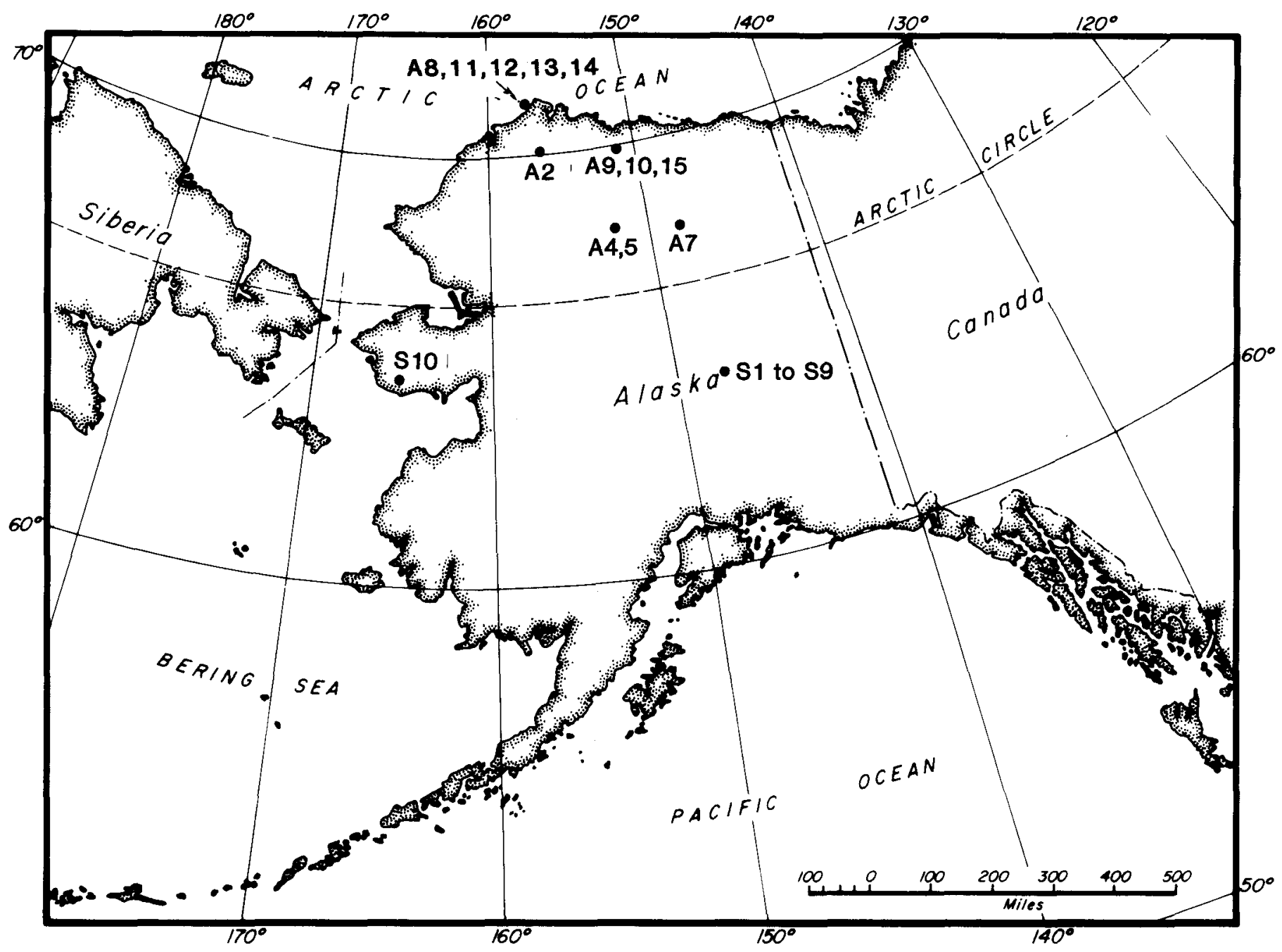

FIG. 1. Locations of the samples analyzed. Refer to Table 1 for further details.

cesium is greatly diluted in seawater and, as a result, the bowhead whale's prey is unlikely to concentrate ${ }^{137} \mathrm{Cs}$, despite high fallout.

\section{${ }^{134} \mathrm{Cs}$ and ${ }^{137} \mathrm{Cs}$ Concentration in Caribou}

The seasonal variation in radiocesium concentrations in caribou muscle samples has been recognized for a long time (Hanson, 1982) and appears to follow the change in the pattern of grazing habits; for example, low values of ${ }^{\mathrm{I} 7} \mathrm{Cs}$ are generally found in caribou muscle tissues following the summer feeding season, when the caribou's diet is mostly vascular plants and sedges. These summer forages contain much lower ${ }^{137} \mathrm{Cs}$ concentrations than do lichens, a forage consumed extensively during winter. Another possible factor of significance for the low ${ }^{737} \mathrm{Cs}$ levels in caribou during summer is the relatively higher excretion of ${ }^{137} \mathrm{Cs}$ during summer as compared to winter (Holleman et al., 1971). It has been shown that the model-derived value of three- to sevenfold increase in radiocesium levels needed to explain the seasonal variation in radiocesium concentration (Holleman et al., 1971) agrees reasonably well with empirical data obtained by Hanson (1982), reporting a five- to tenfold seasonal difference. The muscle sample of caribou harvested in September 1987 has perhaps the lowest ${ }^{137} \mathrm{Cs}$ concentrations reported after the last series of nuclear tests (Table 2).

\section{Permissible Concentrations for Human Consumption}

The maximum permissible intake for ${ }^{137} \mathrm{Cs}$ is approximately $100000 \mathrm{~Bq} / \mathrm{yr}$ for a human adult. This value is calculated from the radiation dose limit for the whole population of $1.7 \mathrm{mSv} / \mathrm{yr}$ (NCRP, 1971) and the radiation dose equivalent of $0.000017 \mathrm{mSv}$ per Bq of ${ }^{137} \mathrm{Cs}$ intake (NCRP, 1977). Such limits suggest permissible concentrations in human food items ranging from $300 \mathrm{~Bq} / \mathrm{kg}$ for milk and meat to $1500 \mathrm{~Bq} / \mathrm{kg}$ for berries and mushrooms. Similar values for permissible concentrations of ${ }^{137} \mathrm{Cs}$ in human foods were adopted by the Scandinavian and European countries following the Chernobyl accident (Jones, 1989). The ${ }^{137} \mathrm{Cs}$ concentrations reported here are substantially less than the acceptable limits, thus suggesting little health risk for persons consuming foods at these ${ }^{13} \mathrm{Cs}$ concentrations. A similar conclusion was reported by Taylor et al. (1988), who assessed the post-Chernobyl radiocesium levels at some localities in northern Canada. 


\section{Deposition of Chernobyl-Derived Radiocesium in Alaska}

The Chernobyl-derived ${ }^{134} \mathrm{Cs}$ in all samples collected in the Arctic, namely, above $67^{\circ} \mathrm{N}$, were below the detection limit with the exception of a single caribou sample. The ${ }^{134} \mathrm{Cs}$ concentration for the caribou sample was $0.4 \mathrm{~Bq} / \mathrm{kg}$, which was only slightly above the detection limit. Perhaps this could be attributed to the fact that snow cover existed on the arctic soil when the Chernobyl plume arrived at the study area and that most of the snow-deposited radiocesium was washed away

TABLE 2. Radiocesium concentrations in selected environmental samples

\begin{tabular}{llclll}
\hline & \multicolumn{3}{c}{ Total activity } & \multicolumn{2}{c}{ Chernobyl-derived } \\
\cline { 2 - 4 } Sample & ${ }^{137} \mathrm{Cs}$ & ${ }^{134} \mathrm{Cs}$ & ${ }^{137} \mathrm{Cs} /{ }^{134} \mathrm{Cs}$ & \multicolumn{2}{c}{${ }^{137} \mathrm{Cs}$} \\
code & $(\mathrm{Bq} / \mathrm{kg})$ & $(\mathrm{Bq} / \mathrm{kg})$ & ratio & $(\mathrm{Bq} / \mathrm{kg})$ & $(\%)$ \\
\hline
\end{tabular}

Arctic soil sediment

$\begin{array}{lccccc}\text { A1 } & 4.1 \pm 4.2 & \text { BD } & - & - & - \\ \text { A2 } & 44.0 \pm 1.3 & \text { BD } & - & - & - \\ \text { A4 } & 2.8 \pm 3.5 & \text { BD } & - & - & - \\ \text { A6 } & 8.1 \pm 1.7 & \text { BD } & - & - & - \\ \text { A7 } & 2.1 \pm 2.2 & \text { BD } & - & - & - \\ \text { A8 } & 2.4 \pm 2.3 & \text { BD } & - & - & -\end{array}$

Arctic lichen, moss, ledum

$\begin{array}{lccccc}\text { A1 } & 16.6 \pm 4.2 & \text { BD } & - & - & - \\ \text { A2 } & 22.3 \pm 1.3 & \text { BD } & - & - & - \\ \text { A3 } & 92.2 \pm 3.5 & \text { BD } & - & - & - \\ \text { A4 } & 39.3 \pm 1.7 & \text { BD } & - & - & - \\ \text { A5 } & 242.0 \pm 2.2 & \text { BD } & - & - & - \\ \text { A6 } & 39.7 \pm 2.3 & \text { BD } & - & - & - \\ \text { A7 } & 58.5 \pm 4.2 & \text { BD } & - & - & -\end{array}$

Arctic fish, whale, caribou

\begin{tabular}{cccccc} 
A9 & BD & BD & - & - & - \\
A10 & $0.52 \pm 0.09$ & BD & - & - & - \\
A11 & & & & & \\
blubber & BD & BD & - & - & - \\
muscle & $0.57 \pm 0.11$ & BD & - & - & - \\
liver & BD & BD & - & - & - \\
A12 & & & & & \\
blubber & BD & BD & - & - & - \\
liver & BD & BD & - & - & - \\
muktuk & BD & BD & - & - & - \\
A13 & $60.0 \pm 4.2$ & BD & - & - & - \\
A14 & $31.0 \pm 1.0$ & $0.4 \pm 0.2$ & 77.0 & 2.1 & 6.8 \\
A15 & $1.1 \pm 0.2$ & BD & - & - & - \\
Subarctic lichen & moss, ledum, mushrooms & & \\
S1 & $97.0 \pm 1.0$ & $5.0 \pm 0.4$ & 19.0 & 27.0 & 27.7 \\
S2 & $89.0 \pm 1.0$ & $4.6 \pm 0.4$ & 19.0 & 24.0 & 27.4 \\
S3 & $86.0 \pm 3.0$ & $6.0 \pm 2.0$ & 14.0 & 32.0 & 37.2 \\
S4 & $60.0 \pm 1.0$ & $4.3 \pm 0.4$ & 14.0 & 23.0 & 38.2 \\
S5 & $3.5 \pm 1.1$ & BD & - & - & - \\
S6 & BD & BD & - & - & - \\
S7 & $3.8 \pm 1.0$ & BD & - & - & - \\
S8 & $32.0 \pm 1.0$ & $1.4 \pm 0.3$ & 23.0 & 8.0 & 24.2 \\
S9 & $43.0 \pm 1.0$ & $5.2 \pm 0.3$ & 8.3 & 28.0 & 65.4 \\
S10 & $51.3 \pm 2.2$ & BD & - & - & - \\
\hline \hline
\end{tabular}

$\mathrm{Bq} / \mathrm{kg}=$ Becquerel per kilogram.

$\mathrm{BD}=$ Below detection. when the snow melted. In this case, we would expect to find high concentrations of radiocesium in lakes in the area. The residence time of radiocesium in lake water was reported to be relatively short. For example, Santschi et al. (1988) showed that about $75 \%$ of the total fallout of ${ }^{134} \mathrm{Cs}$ and ${ }^{137} \mathrm{Cs}$ in Lake Zurich was eliminated from the water column in about six months. Thus, the washed-out radiocesium should reach the bottom of the lake. In order to see if the ${ }^{134} \mathrm{Cs}$ level was high in a bottom sediment sample, one grab sediment sample was collected from a small pond $\left(71.3^{\circ} \mathrm{N}, 156.2^{\circ} \mathrm{W}\right)$ in 1988 and no detectable ${ }^{134} \mathrm{Cs}$ was found in the sample. Also a single sample of lichen (S10) from the extreme west coast of Alaska had no significant ${ }^{134} \mathrm{Cs}$. The ${ }^{134} \mathrm{Cs}$ concentrations in samples from the subarctic Fairbanks area ranged from below detection to 6.0 $\mathrm{Bq} / \mathrm{kg}$. Since lichens were the only environmental samples collected in both the Subarctic and Arctic, these samples were used to assess possible differences in deposition of Chernobylderived radiocesium. Concentrations of ${ }^{134} \mathrm{Cs}$ ranged from below detection $(0.21 \mathrm{~Bq} / \mathrm{kg})$ in all arctic lichen samples to 6.0 $\mathrm{Bq} / \mathrm{kg}$ in a subarctic lichen sample. Assuming that the physical and physiological aspects of lichens are similar at the various collection sites, e.g., lichen density, radiocesium collection efficiency, etc., then the data in this study suggest the deposition rates were highly variable and were greater than a factor of 28.

The present data indicate a low Chernobyl-derived radiocesium deposition in arctic Alaska and on the extreme west coast of Alaska as compared to the subarctic Fairbanks site. It is pertinent to compare this observation with the radioiodine data in the aerosols at Barrow and Fairbanks. The ratio of the timeintegrated concentrations of radioiodine at Barrow to that of Fairbanks was 0.628 just after the Chernobyl accident (5-19 May 1986, unpub. data, Kipphut, 1986). These data are consistent with the observations of others who have investigated distribution of Chernobyl debris in North America. For example, Davidson et al. (1987) determined that Chernobyl-derived radiocesium moved from the U.S.S.R. and Scandinavia over Greenland and into central Canada then spread to the east and west. Assuming that the debris entered Alaska from the east via Canada, deposition should decrease from eastern to western Alaska. Further, if the Chernobyl debris entered Alaska south of the Brooks Mountain Range, deposition may be expected to decrease significantly going from central to northern Alaska.

\section{CONCLUSIONS}

The radiocesium concentrations in all the samples were low and, therefore, present no appreciable health hazard to humans who might consume them directly or indirectly via food chains. The deposition rate of radiocesium from the Chernobyl-derived radiocesium in arctic/subarctic Alaska appears to be highly variable, possibly by a factor of greater than 28. Deposition of radiocesium was greater in subarctic Fairbanks as compared to extreme western and arctic Alaska, which presumably reflects the dispersal pathway of the Chernobyl debris in the area of study.

\section{ACKNOWLEDGEMENTS}

We thank Dr. George Kipphut for providing some of his unpublished data on the radionuclide measurements on air filter samples collected by Dr. Glen Shaw just after the Chernobyl accident. We also express our gratitude to Drs. Peter Santschi and George Kipphut 
for their critical review of an earlier draft of this manuscript. We are grateful to the Department of Wildlife Management, North Slope Borough, Alaska, for their generous cooperation in obtaining pre- and post-Chernobyl event samples from the Alaskan arctic regions. We thank Dr. Gary Laursen, University of Alaska Fairbanks, for his assistance with the acquisition of mushrooms in the Tanana Valley, Alaska. This is Institute of Marine Science Contribution \#837.

\section{REFERENCES}

BAARLI, J., MADSHUS, K., LIDEN, K., and MCCALL, R. 1961. Radiocesium and potassium in Norwegians. Nature 191:436.

BASKARAN, M., KELLEY, J.J., NAIDU, A.S., and HOLLEMAN, D.F. 1988. Radiocesium and radiopotassium concentrations in Alaskan arctic soils, plants and animals. Report No. R88-1. Available at the Institute of Marine Science, University of Alaska Fairbanks, Fairbanks, Alaska 99775-1080.

DAVIDSON, C.I., HARRINGTON, J.R., STEPHENSON, M.J., MONAGHAN, M.C., PUDYKIEWICZ, J., and SCHELL, W.R. 1987. Radioactive cesium from the Chemobyl accident in the Greenland ice sheet. Science 237:633.

GOLDMAN, M. 1987. Chernobyl radiation dose. Science 237:575.

HANSON, W.C. 1967. Radioecological concentration processes characterizing arctic ecosystems. In: Aberg, B., and Hungate, F.P., eds. Radioecological concentration processes. Oxford: Pergamon Press. p. 183. 1982. ${ }^{37} \mathrm{Cs}$ concentrations in northern Alaskan Eskimos, 1962-79: Effects of ecological, cultural and political factors. Health Physics 42:433.

HOLLEMAN, D.F., and STEPHENSON, R.O. 1981. Prey selection and consumption by Alaskan wolves in winter. Journal of Wildlife Management 45(3):620
HOLLEMAN, D.F., LUICK, J.R., and WHICKER, F.W. 1971. Transfer of radiocesium from lichen to reindeer. Health Physics 21:657.

JONES, B.E.V. 1989. Effects of the Chernobyl accident on animal husbandry and production from a Swedish perspective. Journal of American Veterinary Medical Association 194:900.

LIDEN, K., and GUSTAFSON, M. 1967. Relationships and seasonal variation of ${ }^{137} \mathrm{Cs}$ in lichens, reindeer and man in northem Sweden 1961-1965. In: Aberg, B., and Hungate, F.P., eds. Radioecological concentration processes. Oxford: Pergamon Press. p. 93.

MIETTINEN, J.K., and HASANEN, E. $1967 .{ }^{137} \mathrm{Cs}$ in Finnish Lapps and other Finns in 1962. In: Aberg, B., and Hungate, F.P., eds. Radioecological concentrations processes. Oxford: Pergamon Press. p. 261.

NCRP. 1971. Basic radiation protection criteria. National Council on Radiation Protection Report 39.

1977. Cesium-137 from the environment to man. National Council on Radiation Protection Report 52.

PALMER, H.E., HANSON, W.C., GRIFFIN, B.I., and ROESCH, W.C. 1963. Cesium-137 in Alaskan Eskimos. Science 142:64.

SANTSCHI, P.H., BOLLHALDER, S., FARRENKOTHEN, K., LUECK, A., ZINGG, S., and STURM, M. 1988. Chernobyl radionuclides in the environment: Tracers for the tight coupling of atmospheric, terrestrial and aquatic geochemical processes. Environmental Science and Technology 22:510.

SKOGLAND, T. 1987. Radiocesium concentrations in wild reindeer at Dovrefjell, Norway. Rangifer 7(2):42.

TAYLOR, H.W., SVOBODA, J., HENRY, G.H.R., and WEIN, R.W. 1988. Post-Chernobyl ${ }^{134} \mathrm{Cs}$ and ${ }^{133} \mathrm{Cs}$ levels at some localities in northern Canada. Arctic 41(4):293-296.

WATSON, W.S. 1986. Human ${ }^{134} \mathrm{Cs} /{ }^{137} \mathrm{Cs}$ levels in Scotland after Chernobyl. Nature 323:763.

WHITE, R.G., HOLLEMAN, D.F., and ALLAYE-CHAN, A.C. 1986. Radiocesium concentrations in the lichen-reindeer/caribou food chain: Before and after Chernobyl. Rangifer 1:24. 